\title{
Sensitivity of Lymphocytes of Patients with Fibroadenoma and Breast Cancer to Gamma-Rays as Evaluated by Chromosomal Aberrations
}

\author{
Usha Kumari* and G.K. Bhat** \\ *Department of Physiology, **Department of Biochemistry, Kasturba Medical College, \\ Manipal University, Manipal 576 104, Karnataka, India
}

KEYWORDS Breast cancer; chromosomal aberrations; fibroadenoma; lymphocyte culture; radiosensitivity

\begin{abstract}
Radiosensitivity as determined by chromosomal aberrations in lymphocytes of patients suffering from fibroadenoma $(n=31)$ and breast cancer $(n=41)$ and was compared with the data from those of healthy individuals $(\mathrm{n}=10)$. Lymphocytes from healthy control set of individuals were exposed at $\mathrm{G}_{0}$ stage to different doses $(0.5 \mathrm{~Gy}, 1.0$ Gy, $2.0 \mathrm{~Gy}$ and $4.0 \mathrm{~Gy}$ ) of $\gamma$-rays. As over $60 \%$ cells remained viable at a dose of $2 \mathrm{~Gy}$, this dose was selected for further experimentation. Lymphocytes were cultured for 48 hours to obtain data from first mitotic metaphases. Frequencies of chromosomal aberrations namely acentric fragments, double minutes, dicentrics and rings were recorded. Lymphocytes of patients with fibroadenoma or breast cancer exhibited higher radiation sensitivity compared to lymphocytes from healthy individuals. Lymphocytes of patients with different stages of breast cancer showed an increase in the frequency of chromosomal aberrations from stage I to IV.
\end{abstract}

\section{INTRODUCTION}

There exists difference in the radiosensitivity of normal and tumor cells, as assessed from the frequency of chromosomal aberrations and incidence of micronuclei (Vral et al. 2004). Sensitivity of cells to radiation is also known to vary amongst different healthy individuals, which depends on different endogenous and exogenous factors such as genetic constitution, age, sex, exposure to various life style factors and occupation.

Human lymphocytes in culture constitute an ideal test system to evaluate the cytogenetic damage induced by radiation and other environmental agents. Differences in radiosensitivity of lymphocytes between normal individuals and cancer patients can be attributed to multistep process of carcinogenesis comprising of the genomic changes in the transformation of normal cells to malignant cells.

Presence of structural and numerical defects in chromosomes have been reported in lymphocytes of fibroadenoma patients, a premalignant condition (Ozisik et al. 1994). Compared to carci-

Author for correspondence

Dr. Usha Kumari

Department of Physiology, Kasturba Medical College, Manipal University, Manipal 576 104, Karnataka Telephone: 0820-2922321

E-mail: ushaharischandran@yahoo.co.in noma, lymphocytes from fibroadenoma patients exhibit less complex cytogenetic abnormalities (Rizou et al. 2004). It is suggested that fibroadenoma individuals have an increased risk of developing breast cancer (Staats et al. 1998).

Chromosomal preparations obtained from cultured lymphocytes undergoing first division after irradiation at $\mathrm{G}_{0}$ stage with $2 \mathrm{~Gy}$ of $\gamma$-rays, were analyzed to record the aberrations at metaphase. It is reported that $15 \%$ of the patients receiving radiation treatment may be radiosensitive (Kagan 1988). Several earlier studies were aimed at developing methods which can assess in vitro radiosensitivity of normal cells as a predictive assay for normal tissue response or tolerance to radiotherapy (West et al. 1995; Guiaraud et al. 2005 ) and also may provide the basis for individualizing radiotherapy schedules (Burnet et al. 1992, 1994; Mackay and Hendry 1999). These findings also suggest the need to further carryout tests to determine chromosomal radiosensitivity of patients who are advised radiotherapy. The study described here is an attempt to examine the radiosensitivity of normal lymphocytes from healthy individuals, premalignant lymphocytes from patients with fibroadenoma and of lymphocytes of patients suffering from breast cancer.

Breast cancer patients of different stages (IIV) and the incidence of aberrations in different age groups of patients also examined. 


\section{MATERIALS AND METHODS}

Five milli liter of heparinized venous blood was collected under sterile conditions from healthy individuals $(\mathrm{n}=10)$, patients with fibroadenoma $(n=31)$ and patients suffering from breast cancer $(n=41)$. The blood samples were collected as per the institutional ethical guidelines. Cells were irradiated and cultured within one hour of collection of blood. To each of the culture vials $0.5 \mathrm{ml}$ of blood was put and irradiated with $\gamma$-rays at different doses (each with $0.5 \mathrm{~Gy}$, $1.0 \mathrm{~Gy}, 2.0 \mathrm{~Gy}$ or $4.0 \mathrm{~Gy}$ ). Irradiation was carried out employing telecobalt unit Theratron $780 \mathrm{C}$, AECL, Canada, available at the Department of Radiotherapy of Kasturba Hospital, Manipal, with mean dose-rate of $261.82 \mathrm{cGy} / \mathrm{min}$ at $78.5 \mathrm{~cm} \mathrm{SSD}$.

Cultures were set after the addition of phytohaemagglutinin ( $5 \mu \mathrm{g} / \mathrm{ml}$-sigma), and maintained at $37^{\circ} \mathrm{C}$ for $48 \mathrm{~h}$. Colchicine (final concentration, $5 \mu \mathrm{g} / \mathrm{ml}$-sigma) was added to each vial and after $2 \mathrm{~h}$ cells were harvested. They were centrifuged at $800 \mathrm{rpm}$ and exposed to prewarmed $0.56 \% \mathrm{KCl}$ at $37^{\circ} \mathrm{C}$ for $10 \mathrm{~min}$, and were then fixed in methanol: acetic acid (3:1). The fixative was changed three times, each time after centrifugation. Chromosomal preparations were obtained from fixed cell suspensions dropped on clean chilled slide, each of which was air dried. Slides were stained with Giemsa solution $(6 \%)$ for 10 min and analyzed to score the frequency of chromosomal aberrations namely, acentric fragments, double minutes, rings and dicentrics (Savage 1976).

Slides were coded and scored by single observer. Hundred metaphases were scored per subject. The data from healthy control set of samples helped in the selection of dose. Incidence of chromosomal aberrations showed a dosedependent increase with an increase in the radiation dose from $0.5 \mathrm{~Gy}$ to $4.0 \mathrm{~Gy}$. There was an inverse relationship between radiation dose and the viability of irradiated cells, as judged from preparations using trypan blue. Taking cell viability and frequency of chromosomal aberrations it was proposed to expose cells to $\gamma$-rays at a dose of $2 \mathrm{~Gy}$ for further experimentation.

Data obtained from irradiated and control set of samples were subjected to regression analysis to examine dose-response relationship. Linear regression was calculated as $C+\alpha D$, and linear quadratic function was calculated by the formula $\mathrm{C}+\alpha \mathrm{D}+\beta \mathrm{D}^{2} ;$ where $\mathrm{C}, \alpha$ and $\beta$ denoted estimated parameters for spontaneous and radiation induced chromosomal aberrations, and $\mathrm{D}$, the radiation dose in Gy.

To identify the degree of radiosensitivity the rate of increase of aberration frequency from baseline to radiation - induced levels was recorded. Degree of increase in aberration frequency was categorized into 1.0-1.5, 1.6-2.0, 2.1-2.5, 2.6-3.0, 3.1-3.5 times and so on, by introducing a step of "0.5 times" at each level. Based on this the degree of increase of aberration frequency was divided into three levels, namely less radiosensitive $(\leq 2$ times), moderately radiosensitive ( $>2$ to 5 times), and highly radiosensitive ( $>5$ times).

All the tests were carried out using SPSSPC 4.0 statistical software. Mean, standard deviation, standard error and $95 \%$ confidence interval of data were calculated using descriptive statistics. One-way ANOVA test was applied to measure aberrations in different subgroups. Influence of age of patients on aberration freque-ncy was assessed using multivariant ANOVA test.

\section{RESULTS}

A dose-dependent decrease in survival of cells was observed with increase in the radiation dose. Cell viability tested at 72 hours of culture using trypan blue was $75 \%$ with $0.5 \mathrm{~Gy}, 70 \%$ with $1.0 \mathrm{~Gy}, 64 \%$ with $2.0 \mathrm{~Gy}$ and $40 \%$ with $4.0 \mathrm{~Gy}$ of $\gamma$ rays. The incidence of chromosomal aberrations was found to increase with increase in radiation dose. It was $8.9 \%, 14 \%, 21 \%$ and $34 \%$ on exposure to $0.5 \mathrm{~Gy}, 1.0 \mathrm{~Gy}, 2.0 \mathrm{~Gy}$ and $4.0 \mathrm{~Gy}$ of $\gamma$-rays respectively. A dose of $2.0 \mathrm{~Gy}$ of radiation was chosen for further experimentation, taking cell viability and chromosomal aberrations into consideration.

The study was conducted on blood samples obtained from 82 subjects. Of these the control set consisted of 10 individuals (12.2\%), 31 patients with fibroadenoma (37.8\%) and 41 patients $(50 \%)$ suffering from breast cancer. Breast cancer patients were further grouped based on clinical stage of the cancer and stage I consisted of $8(19.5 \%)$, stage II of $12(29.3 \%)$, stage III of 9 (21.9\%) and stage IV included 12 (29.3\%) patients. Thirty seven subjects $(45 \%)$ tested were over 40 years of age. Those less than 20 years were only three $(<4 \%)$ and individuals in the age group of 21-40 years were forty two in number $(>51 \%)$. 
Table 1: Mean percentage of aberrant metaphase plates on exposure to $\gamma$-rays $(2 \mathrm{~Gy}$ )

\begin{tabular}{lccc}
\hline Group & $\begin{array}{c}\text { Sample } \\
\text { size }(n)\end{array}$ & $\begin{array}{c}\text { Non- } \\
\text { irradiated } \\
\text { mean } \pm S D\end{array}$ & $\begin{array}{c}\text { Irradiated } \\
\text { mean } \pm S D\end{array}$ \\
\hline 1. Control & 10 & $1.16 \pm 0.40$ & $2.88 \pm 0.98$ \\
2. Fibroadenoma & 31 & $2.06 \pm 1.25$ & $7.00 \pm 2.83$ \\
3. Breast cancer & 41 & $3.50 \pm 1.79$ & $20.98 \pm 12.5$ \\
$\quad$ (Data pooled & \\
$\quad$ from all the stages) \\
Stages of Breast cancer \\
4. Stage I & 08 & $1.74 \pm 0.87$ & $11.84 \pm 4.36$ \\
5. Stage II & 12 & $2.70 \pm 0.85$ & $13.47 \pm 5.39$ \\
6. Stage III & 09 & $3.79 \pm 1.18$ & $21.81 \pm 10.21$ \\
7. Stage IV & 12 & $5.26 \pm 1.76$ & $33.96 \pm 12.05$ \\
\hline Non-irradiated: p<0.05: (3 vs 1,2$)(7$ vs $1,4,5)(6$ vs \\
1,4) \\
Irradiated: p<0.05: (3 vs 1,2$)(7$ vs $1,4,5,6)(6$ vs 1$)$
\end{tabular}

In non-irradiated samples, higher frequency of aberrant metaphases were observed (Table 1) in breast cancer patients in comparison to fibroadenoma and control (i.e 1.7 and 3 times respectively) sets and this was statistically significant $(\mathrm{p}<0.05)$. Further a stage wise increase in the aberrant metaphases, i.e. in comparison to stage I, stage IV showed 3 times more aberrant metaphases $(\mathrm{p}<0.05)$.

Irradiation resulted in an increase in the frequency of aberrant metaphases (Table 1). Cells of healthy individuals showed more than two fold increase in aberrant cells on exposure to gamma rays, while cells of fibroadenoma patients exhibited more than three fold increase, and there was about six fold increase in the lymphocytes of breast cancer patients. The degree of increase was statistically significant in breast cancer set compared to control and fibroadenoma sets. Further progressive and significant increase was found from stage I to stage IV $(\mathrm{p}<0.05)$.

Frequency of various types of chromosomal aberrations and total aberrations are detailed in Tables 2-6. Each of the aberration types namely dicentrics, rings, double minutes, acentric fragments, exhibited an increase in their frequency in non-irradiated lymphocytes of fibroadenoma patients compared to those of the lymphocytes of healthy individuals. The increase was found to be much more higher in breast cancer patients in comparison with patients suffering from fibroadenoma. A similar trend was also observed in lymphocytes of the three groups after irradiation. Significance levels are indicated below each table.

A perusal of the data presented in Table 7 indicates that lymphocytes of healthy
Table 2: Dicentrics per 100 metaphases scored per subject on exposure to radiation $(\gamma$-rays, 2 Gy)

\begin{tabular}{lrrr}
\hline Group & $\begin{array}{c}\text { Sample } \\
\text { size (n) }\end{array}$ & $\begin{array}{c}\text { Non- } \\
\text { irradiated } \\
\text { mean } \pm S D\end{array}$ & \multicolumn{1}{c}{$\begin{array}{c}\text { Irradiated } \\
\text { mean } \pm S D\end{array}$} \\
\hline 1. Control & 10 & $0.30 \pm 0.48$ & $0.59 \pm 0.64$ \\
2. Fibroadenoma & 31 & $0.47 \pm 0.69$ & $3.18 \pm 1.96$ \\
3. Breast cancer & 41 & $1.65 \pm 1.44$ & $13.45 \pm 8.11$ \\
$\quad$ (Data pooled & & \\
$\quad$ from all the stages) & & \\
Stages of Breast cancer & & \\
4. Stage I & 08 & $1.23 \pm 1.13$ & $7.71 \pm 3.42$ \\
5. Stage II & 12 & $1.55 \pm 1.05$ & $9.64 \pm 4.99$ \\
6. Stage III & 09 & $1.14 \pm 1.32$ & $12.01 \pm 6.24$ \\
7. Stage IV & 12 & $2.42 \pm 1.84$ & $22.15 \pm 7.36$ \\
\hline
\end{tabular}

Non-irradiated: $\mathrm{p}<0.05$ : (3 vs 1,2$)$ (7 vs 1$)$ Irradiated: $\mathrm{p}<0.05$ : (3 vs 1,2$)(7$ vs $1,4,5,6)$ (6 vs 1$)$ (5 vs 1)

Table 3: Rings per 100 metaphases scored per subject on exposure to radiation $(\boldsymbol{\gamma}$-rays, 2 Gy)

\begin{tabular}{lccc}
\hline Group & $\begin{array}{c}\text { Sample } \\
\text { size }(n)\end{array}$ & $\begin{array}{c}\text { Non- } \\
\text { irradiated } \\
\text { mean } \pm S D\end{array}$ & $\begin{array}{c}\text { Irradiated } \\
\text { mean } \pm S D\end{array}$ \\
\hline 1. Control & 10 & $0.10 \pm 0.32$ & $0.64 \pm 0.73$ \\
2. Fibroadenoma & 31 & $0.52 \pm 0.65$ & $1.14 \pm 1.37$ \\
3. Breast cancer & 41 & $0.91 \pm 0.85$ & $6.19 \pm 3.97$ \\
$\quad$ (Data pooled \\
$\quad$ from all the stages) \\
Stages of Breast cancer \\
4. Stage I & 08 & $0.50 \pm 0.53$ & $3.46 \pm 2.29$ \\
5. Stage II & 12 & $1.43 \pm 0.67$ & $5.53 \pm 3.23$ \\
6. Stage III & 09 & $0.84 \pm 1.07$ & $5.03 \pm 2.99$ \\
7. Stage IV & 12 & $0.72 \pm 0.84$ & $9.55 \pm 4.23$ \\
Non-irradiated: $<<0.05:(3 \mathrm{v} / \mathrm{s} 1)(5 \mathrm{v} / \mathrm{s} 1)$ \\
Irradiated: $\mathrm{p}<0.05:(3 \mathrm{v} / \mathrm{s} 1,2)(7 \mathrm{v} / \mathrm{s} 1,4,5,6)(5 \mathrm{v} / \mathrm{s} 1)$
\end{tabular}

Table 4: Double minutes per 100 metaphases scored per subject on exposure to radiation $(\gamma$-rays, 2 Gy)

\begin{tabular}{lccc}
\hline Group & $\begin{array}{c}\text { Sample } \\
\text { size }(n)\end{array}$ & $\begin{array}{c}\text { Non- } \\
\text { irradiated } \\
\text { mean } \pm S D\end{array}$ & $\begin{array}{c}\text { Irradiated } \\
\text { mean } \pm S D\end{array}$ \\
\hline 1. Control & 10 & $0.39 \pm 0.50$ & $0.61 \pm 0.90$ \\
2. Fibroadenoma & 31 & $1.22 \pm 0.83$ & $2.02 \pm 1.14$ \\
3. Breast cancer & 41 & $1.59 \pm 0.89$ & $5.95 \pm 3.41$ \\
(Data pooled & & \\
from all the stages) & \\
Stages of Breast cancer \\
4. Stage I & 08 & $1.13 \pm 0.99$ & $3.36 \pm 1.33$ \\
5. Stage II & 12 & $1.98 \pm 0.98$ & $4.70 \pm 1.44$ \\
6. Stage III & 09 & $1.19 \pm 0.58$ & $6.20 \pm 3.17$ \\
7. Stage IV & 12 & $1.79 \pm 0.73$ & $8.74 \pm 4.07$ \\
\hline Non-irradiated: p<0.05: (2,3 vs 1$)(7$ vs 1$)(5$ vs 1$)$ \\
Irradiated: $\mathrm{p}<0.05:(3$ vs 1,2$)(7$ vs $1,4,5)(6$ vs 1$)(5$ vs 1$)$
\end{tabular}

individuals are either less or moderately radiosensitive. A large proportion of lymphocytes of fibroadenoma patients exhibited either less or moderate radiosensitivity and only about $16 \%$ of them exhibited high radiosensitivity. Compared 
Table 5: Acentric fragments per 100 metaphases scored per subject on exposure to radiation $(\gamma$ rays, 2 Gy)

\begin{tabular}{|c|c|c|c|}
\hline Group & $\begin{array}{l}\text { Sample } \\
\text { size }(n)\end{array}$ & $\begin{array}{c}\text { Non- } \\
\text { irradiated } \\
\text { mean } \pm \text { SD }\end{array}$ & $\begin{array}{l}\text { Irradiated } \\
\text { mean } \pm S D\end{array}$ \\
\hline 1. Control & 10 & $0.59 \pm 0.51$ & $1.43 \pm 0.52$ \\
\hline 2. Fibroadenoma & 31 & $1.60 \pm 0.81$ & $2.93 \pm 1.59$ \\
\hline $\begin{array}{l}\text { 3. Breast cancer } \\
\text { (Data pooled } \\
\text { from all the } \mathrm{s}\end{array}$ & tages) & $1.89 \pm 1.02$ & $5.94 \pm 4.06$ \\
\hline \multicolumn{4}{|c|}{ Stages of Breast cancer } \\
\hline 4. Stage I & 08 & $1.25 \pm 0.89$ & $4.36 \pm 1.83$ \\
\hline 5. Stage II & 12 & $2.13 \pm 1.06$ & $4.93 \pm 1.95$ \\
\hline 6. Stage III & 09 & $1.87 \pm 0.95$ & $4.92 \pm 2.51$ \\
\hline 7. Stage IV & 12 & $2.10 \pm 1.04$ & $8.78 \pm 6.08$ \\
\hline
\end{tabular}

Table 6: Total number of chromosomal aberrations per 100 metaphases scored per subject on exposure to radiation $(\boldsymbol{\gamma}$-rays, 2 Gy $)$

\begin{tabular}{|c|c|c|c|}
\hline Group & $\begin{array}{l}\text { Sample } \\
\text { size }(n)\end{array}$ & $\begin{array}{c}\text { Non- } \\
\text { irradiated } \\
\text { mean } \pm S D\end{array}$ & $\begin{array}{l}\text { Irradiated } \\
\text { mean } \pm S D\end{array}$ \\
\hline 1. Control & 10 & $1.35 \pm 0.48$ & $3.29 \pm 0.68$ \\
\hline 2. Fibroaden & ma 31 & $3.60 \pm 1.69$ & $9.26 \pm 4.33$ \\
\hline $\begin{array}{l}\text { 3. Breast can } \\
\text { (Data poo } \\
\text { from all tl }\end{array}$ & $\begin{array}{l}\text { cer } 41 \\
\text { led } \\
\text { le stages) }\end{array}$ & $5.99 \pm 2.65 \quad 3$ & $31.54 \pm 16.9$ \\
\hline Stages of Brea. & $t$ cancer & & \\
\hline 4. Stage I & 08 & $4.10 \pm 2.57$ & $18.87 \pm 6.96$ \\
\hline 5. Stage II & 12 & $6.91 \pm 3.02 \quad 2$ & $24.82 \pm 10.22$ \\
\hline 6. Stage III & 09 & $5.07 \pm 1.58$ & $28.18 \pm 12.55$ \\
\hline 7. Stage IV & 12 & $7.02 \pm 2.22 \quad 4$ & $49.22 \pm 16.50$ \\
\hline $\begin{array}{l}\text { Non-irradiated: } \\
\text { Irradiated: } \mathrm{p}<0 \text {. }\end{array}$ & $\begin{array}{l}\mathrm{p}<0.05:(2, \\
5:(3 \text { vs } 1,2\end{array}$ & $\begin{array}{l}, 3 \text { vs } 1)(7,5 \text { vs } \\
2)(7 \text { vs } 1)\end{array}$ & \\
\hline $\begin{array}{l}\text { Table } 7 \text { : Distr } \\
\text { radiosensiti }\end{array}$ & $\begin{array}{l}\text { oution of sub } \\
\text { ty }\end{array}$ & bjects & basis \\
\hline Group & $\begin{array}{c}\text { Healthy } \\
\text { individuals } \\
(n \%)\end{array}$ & $\begin{array}{c}\text { Fibroade- } \\
\text { noma } \\
\text { patients }(n \%)\end{array}$ & $\begin{array}{c}\text { Breast } \\
\text { cancer } \\
\text { o) patients } \\
\end{array}$ \\
\hline Less & $2(20 \%)$ & $13(41.9 \%)$ & $5(12.2 \%)$ \\
\hline $\begin{array}{l}\text { radiosensitive } \\
\text { Moderately } \\
\text { radiosensitive }\end{array}$ & $8(80 \%)$ & $13(41.9 \%)$ & $12(29.3 \%)$ \\
\hline $\begin{array}{l}\text { Highly } \\
\text { radiosensitive }\end{array}$ & - & $5(16.2 \%)$ & $24(58.5 \%)$ \\
\hline
\end{tabular}

Table 8 : Age-wise distribution of aberrant metaphases and chromosomal aberrations in subjects (control, fibroadenoma and breast cancer patients) exposed to radiation $(\boldsymbol{\gamma}$-rays, 2 Gy)

\begin{tabular}{cccccc}
\hline $\begin{array}{c}\text { Age } \\
\text { group }\end{array}$ & $\begin{array}{c}\text { Aberrant } \\
\text { metaphases }(\%)\end{array}$ & & \multicolumn{2}{c}{$\begin{array}{c}\text { Total } \\
\text { aberrations (\%) }\end{array}$} \\
\cline { 2 - 3 } \cline { 5 - 6 } & NI & IRR & & NI & IRR \\
\hline$\leq 20$ & 2.96 & 8.4 & & 4.74 & 15.26 \\
$21-30$ & 2.49 & 12.37 & & 3.27 & 18.25 \\
$31-40$ & 2.70 & 12.96 & & 4.31 & 18.18 \\
$41-50$ & 2.74 & 14.97 & & 4.85 & 21.4 \\
$51-60$ & 2.44 & 13.56 & & 5.34 & 22.67 \\
\hline
\end{tabular}

$\mathrm{NI}=$ Non irradiated

IRR = Irradiated to this, lymphocytes of $60 \%$ breast cancer patients exhibited high radiosensitivity.

Individuals of various age groups $(\leq 20 \mathrm{y} ; 21$ $30 y ; 31-40 y$; 41-50y; 51-60y) were examined for the frequency of cytogenetic damage (Table 8). These individuals on irradiation, showed gradual increase in aberrations, indicating that with increase in age, there is increase in radiosensitivity.

\section{DISCUSSION}

Chromosomal aberrations caused by radiation are direct indicators of genetic damage and they are employed for the determination of radiosensitivity of individuals (Coskun et al. 2000). The present study has been carried out to evaluate the radiosensitivity of lymphocytes of patients with breast cancer, of patients with fibroadenoma and of healthy individuals.

A total of 82 samples of lymphocytes obtained from forty one cases of breast cancer, thirty one cases of fibroadenoma and ten healthy individuals constituted the material for the study. They were exposed to radiation (gamma rays: $2 \mathrm{~Gy}$ ) and the first metaphases were analysed to record the incidence of chromosomal aberrations, consisting of acentric fragments, double minutes, rings and dicentrics. It is suggested that each laboratory should establish its own control dose response data for radiation (Coskun et al. 2000) and this study is an attempt in that direction.

The frequency of dicentrics observed in the control set of healthy individuals is comparable to the data presented by Slyper et al. (2000) and Coskun et al. (2000). The increased presence of double minutes in breast cancer patients is suggestive of the role of gene amplification in carcinogenesis (Gebhart et al. 1986; Madhavi et al. 1990). The type of chromosomal aberrations is dependent on the stage of the cell at which it is exposed to radiation. Double strand breaks which fail to repair leads to cell lethality (Iliakis and Pantelias 1990).

Higher radiosensitivity observed in the lymphocytes of breast cancer patients is in agreement with the findings of Matsubara et al. (1988), Barrios et al. (1990), Wojcik et al. (2003) and of Baeyens et al. (2005). Jones et al. (1995), had determined radiosensitivity of breast cancer patients employing chromosomal abnormality assay. Baeyens et al. (2004) carried out a detailed study on chromosomal radiosensitivity of familial breast cancer patients carrying mutation in BRCA1 or BRCA2 and compared the findings to 
a reference group of breast cancer patients without mutation and a group of healthy women. Chromosomal mutagen sensitivity associated with BRCA genes was also investigated by Speit and Trenz (2004).

The observations from this study also indicates that with an increase in the age of the individuals, there is increase in radiosensitivity and the observations are in agreement with those of Joksie et al. (2004). The necessity to develop simple evaluation procedure is to predict tissue response to radiotherapy with a view to lessen morbidity rate and to increase the dose of radiation in resistant individuals, as has been stressed by Jones et al. (1995). The findings recorded in this study provide data on the radiosensitivity of healthy individuals, patients with fibroadenoma or with breast cancer. Fibroadenoma is considered a precancerous condition and frequency of chromosomal aberrations also indicate this phenomenon in comparison with normal cells and cells of breast cancer patients. It is suggested that such an assessment needs to be carried out on patients who are advised radiotherapy, before they are subjected to irradiation.

\section{ACKNOWLEDGEMENTS}

This research was supported by grants from the Manipal University. We are indebted to Dr. P. M. Gopinath, Dr. K. Satyamoorthy, Dr. B.S. Sathish Rao and Dr. Susan Benjamin for their support in preparing the manuscript.

\section{REFERENCES}

Baeyens A, Broecke RVD, Makar A, Thierens H, Ridder LD, Vral A 2005. Chromosomal radiosensitivity in breast cancer patients: influence of age of onset of the disease. Oncology Report, 13: 347-353.

Baeyens A, Thierens H, Claes K, Poppe B, Ridder LD, Vral A 2004. Chromosomal radiosensitivity in BRCA1 and BRCA2 Mutation carriers. Int J Radiat Biol, 80: 4 745-756.

Barrios L, Caballón MR, Miro R, Fuster C, Guedea F, Subias A, Egozcue J 1990. Cytogenetic effects of radiotherapy: frequency and types of chromosome aberrations. Int J Radiat Oncol Biol Phys, 19: 371-375.

Burnet NG, Nyman J, Turesson I, Wurm R, Yernold JH, Peacock JH 1994. The relationship between cellular radiation sensitivity and tissue response may provide the basis for individualizing radiotherapy schedules. Radiother Oncol, 33: 228-38.

Burnet NG, Nyman J, Turesson I, Wurm R, Yernold JH, Peacock JH 1992. Prediction of normal-tissue tolerance to radiotherapy from in-vitrocellulae radiation sensitivity. Lancet, 339: 1570-1

Coskun M, Asli T, Tuncay O 2000. Biological dosimetry following X-ray Irradiation. Tr J of $\mathrm{Med} \mathrm{Sci}$, 30: 563-569.

Gebhart E, Bruderlein S, Augustus M, Siebert E, Feldner J, Schmidt W 1986. Cytogenetic studies on human breast carcinomas. Breast Cancer Res Treat, 8: 125 38

Guiaraud-Vitaux F, Jacquet N, Petiet A, Roy L, Voisin P 2005. Induction of unstable and stable chromosomal aberrations by $99 \mathrm{mTc}$ : in-vitro and in-vivo studies. Nucl Med Commun, 26: 913-8.

Iliakis GE and Pantelias GE 1990. Production and repair of chromosome damage in an X-ray sensitive $\mathrm{CHO}$ mutant visualized and analysed in interphase using the technique of premature chromosome condensation. Int J Radiat Biol, 57: 1213-1223.

Joksie G, Petrovie S, Ilic Z 2004. Age related changes in radiation-induced micronuclei among healthy individuals. Braz J Med Biol Res, 37: 1111-1117.

Jones LA, Scott D, Cowan R, Robert SA 1995. Abnormal radiosensitivity of lymphocytes from breast cancer patients with excessive normal tissue damage after radiotherapy: Chromosome aberrations after low dose-rate irradiation. Int J Radiat Biol, 67: 519528.

Kagan AR 1988. The importance of genetics for the optimization of radiation therapy. Am J Clin Oncol, 11: $84-88$

Mackay RT and Hendry JH 1999. The modeled benefits of individualizing radiotherapy patient's dose using cellular radiosensitivity assays with inherent variability. Radiother Oncol, 50: 67-75.

Madhavi R, Guntur M, Ghosh R, Ghosh PK1990. Double minute chromosomes in the leukocytes of a young girl with breast carcinoma. Cancer Genet Cytogenet, 44: 203-7.

Matsubara S, Saito F, Suda T, Fijibayashi H, Shibuya H, Horiuchi J, Suzuki S 1988. Radiation injury in a patient with unusually high sensitivity to radiation. Acta Oncol, $27:$ 67-71.

Ozisik Y.Y, Morgan R, Peier A, Meloni AM, Sandberg AA.1994. Trisomy 5 in long-term cultures from bone marrow of patients with solid tumors. Cancer Genet Cytogenet, 78: 207-209.

Rizou H, Bardi G, Arnaourti M, Apostolikas N, Sfikas K, Charlaftis A, Polichronis A, Agnantis NJ, Pandis N 2004. Metaphase and Interphase cytogenetics in fibroadenomas of the breast. In vivo, 18: 703711

Savage J.R 1976. Classification and relationships of induced chromosomal structural changes. J Med Genet, 13: 103-122.

Slyper AH, Shadley JD, Tuinen PV, Richton SM 2000. A study of chromosomal aberrations and chromosomal fragility after recombinant growth hormone treatment. Pediatr Research, 47: 634639.

Speit G and Trenz K 2004. Chromosomal mutagen sensitivity associated with Mutations in BRCA genes. Cytogenet Genome Res, 104: 325-332.

Staats B, Bonk U, Gohla G, Bartnitzke S, Bullerdiek J 1998. Two cases of fibrocystic disease with polysomy 18 as the sole clonal cytogenetic abnormality. Cancer Genet Cytogenet, 103: 91-94. Vral A, Thierens H, Baeyens A, De Ridder L 2004. 
Chromosomal aberrations and in vitro radiosensitivity: intra-individual versus interindividual variability. Toxicol Lett, 149: 345-52.

West CM, Elyan SA, Berry P, Cowan R, Scott D 1995. A comparison of the radiosensitivity of lymphocytes from normal donars, cancer patients, individuals with ataxia-telangiectasia (A-T) and A-T heterozygotes. Int J Radat Biol, 68:197-203.

Wojcik A, Stephan G, Sommer S, Buraczewska I, Kuszewski T, Gozdz S 2003. Chromosomal aberrations and micronuclei in lymphocytes of breast cancer patients after an accident during radiotherapy with $8 \mathrm{MeV}$ electrons. Radiat Res, 160: $677-83$. 